\title{
Numerical Simulation of Sea Breeze Convergence over Antarctic Peninsula
}

\author{
Alcimoni Nelci Comin and Otávio Costa Acevedo \\ Department of Physics, Federal University of Santa Maria, Santa Maria, RS, Brazil \\ Correspondence should be addressed to Alcimoni Nelci Comin; alcimoni.comin@gmail.com
} and Otávio Costa Acevedo; otavio@ufsm.br

Received 2 August 2016; Revised 18 October 2016; Accepted 20 November 2016; Published 4 January 2017

Academic Editor: Stefano Federico

Copyright (C) 2017 A. N. Comin and O. C. Acevedo. This is an open access article distributed under the Creative Commons Attribution License, which permits unrestricted use, distribution, and reproduction in any medium, provided the original work is properly cited.

\begin{abstract}
The convergence zone induced by sea breeze systems over Antarctic Peninsula is analyzed for the summer season of 2013-2015. 59 days, selected by satellite images for the absence of major synoptic forcing, are simulated using the WRF model. Sea breeze convergence has been detected in 21 of these days, mostly during evening hours and under large-scale winds. Breeze events are associated with a cold anomaly at the peninsula with respect to the climatology. This condition favors the onset of the necessary horizontal thermal gradients to trigger the breeze circulation. At the same time, no anomaly of the average pressure at sea level is found, indicating that events are favored when the average synoptic flow is present. Case studies indicate that the convergence location over the peninsula is controlled by the synoptic wind. An average convergence over the peninsula happens from 14:00 to 22:30 UTC, with a maximum at 18:00 UTC. There is a strong potential temperature gradient between the surface of the peninsula and the sea, with the sea breeze circulation system extending up to $1.2 \mathrm{~km}$ or higher. The sensible heat flux reaches $80 \mathrm{~W} / \mathrm{m}^{2}$ at the top of mountains and $10 \mathrm{~W} / \mathrm{m}^{2}$ near the coast.
\end{abstract}

\section{Introduction}

Although many studies have analyzed the flow characteristics over mountains in the Antarctic [1-3], there are not many that focus on the Antarctic Peninsula (AP). The AP differs from the other mountain ranges by having one side attached to the high mountain plateau of Western Antarctica and the Transantarctic mountains, which effectively blocks low-level flow from passing around the peninsula's southern end. This study attempts to fulfill this deficiency by using Weather Research and Forecasting (WRF) numerical mesoscale model to do the following: answering whether sea breeze convergence occurs over the AP; defining the conditions that favor such occurrence; describing the most relevant characteristics of such events.

The AP stretches approximately northward from $73^{\circ}$ to $62^{\circ} \mathrm{S}$ for about $1500 \mathrm{~km}$ and terrain at the AP may be as high as $2000 \mathrm{~m}$, acting sometimes as obstacle for the strong westerly winds that dominate the mean atmospheric circulation around Antarctica (Orr et al. [4]). Observations at Bellingshausen, situated at the northern tip of the AP, show that from 1969 to 1998 the mean westerly flow at a height of $850 \mathrm{hPa}$ increased from around 7 to $12.5 \mathrm{~m} / \mathrm{s}$ [5]. Summer temperatures are significantly warmer than the colder continental air found east of the Peninsula [5], so that appreciable horizontal thermal gradients may occur.

Previous studies have reported interesting local circulation effects at the AP. A wind speed maximum close to the surface is frequently observed in its eastern portion, in a phenomenon known as the barrier wind jet [6]. It is formed by cold air advected from the southeast, which piles up against the AP mountains and creates a pressure gradient that forces a cold southerly flow. West of the AP, the upper-air winds are deflected towards the south, in summer, transporting relatively warm and moist maritime air towards the ice sheet [7]. In summer, near-surface winds over the ocean are largely blocked by the mountain west of the AP. The winds veer towards the south, following the topography, but are weak [4]. Changes in near-surface wind speed and direction are also related to changes in sea-ice fraction [8]. 
In summer, katabatic winds are weaker than in winter because of differences in how much heat can be lost from the source region and to local sea breezes. The sea breezes dominate the summer wind regime because of the heating of the soil-covered valley floors compared to the cooler ice-covered ocean [9]. Périard and Pettrè [10] found that, during the summer, sea breezes can occur at the coast due to the temperature contrast between the ocean and the Antarctic continent. They also showed that the occurrence of strong winds observed during the interseasons (summer and winter), during which the sea-ice covers the ocean, reduces the temperature contrasts and the consequent likelihood of breeze events.

Outside the AP, at the Adelie Land coast, in Antarctica, Pettrè et al. [11] showed that, during spring and summer, relatively intense solar radiation is received at the surface, warming the lower atmosphere and resulting in the development of relatively frequent sea breeze circulations. To substantiate that a sea breeze circulation can occur, the temperature gradient between two weather stations has been computed from data collected from October to February [11]. The results showed that a temperature gradient large enough to produce a sea breeze circulation may indeed occur.

If the synoptic forcing is weak, the development of local circulations dominates [12]. The complex and smallscale features of sea breezes [13], due, for example, to the complexity of the coastline, make their short-term forecast particularly difficult [14]. The location and duration of the precipitation caused by sea breeze convergence are controlled by the extent and depth of convergence at low levels [15]. The sea breeze circulation cell over the ocean is still poorly understood and documented [16]. Federico et al. [17] showed that sea breezes dominate the local circulation and play a major role in the local climate.

Azorin-Molina et al. [18] showed that the effect of sea breeze is the increase of stratus and cumulus cloud coverage. Observations made by Roberts et al. [19] at Mill Island, east Antarctic, during the austral summer (2009/2010), showed that the sea breeze causes the development of a marine fog layer at surface level over the summit that persisted during the afternoon into the evening. Ramis and Alonso [20] used geostationary visible imagery to show the development of the sea breeze zonal convergence in the center of the island. Comin et al. [21] also used imagery satellite and radar to show the development of the sea breeze zonal convergence in Salento Peninsula. Mazon and Pino [22] showed that the interaction between a cold air mass driven by land breeze with a warmer and wetter prevailing synoptic flow may cause precipitation bands near the coastline. The transition between land/sea breezes occurs in distinct steps, according to the observed temporal evolution of the wind and temperature in the lower atmosphere [23].

This study aims to analyze the frequency, location, and characteristics of the different sea breeze systems over the AP. Meteorological patterns associated with these events are determined by synoptic maps and numerical simulations using state-of-the-art limited area Weather Research and Forecasting (WRF) model. In Section 2, model settings and the simulations are described, while the criteria for the day

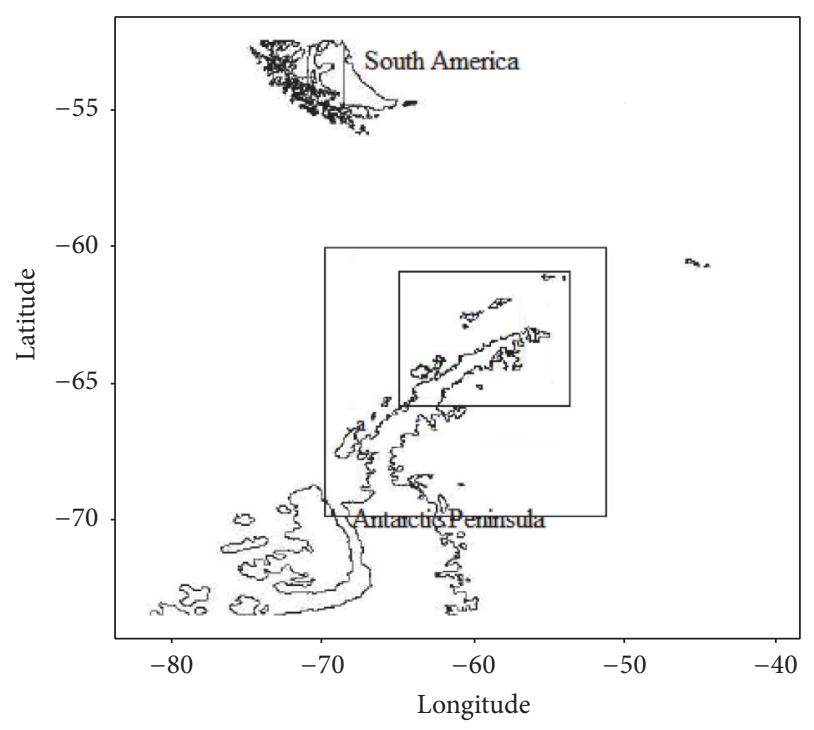

FIGURE 1: Map showing the domains of the simulations with respect to the Antarctic Peninsula.

selection and synoptic analysis are presented in Section 3. The characteristics of the simulated sea breeze events are provided in Section 4 and conclusions are given in Section 5.

\section{The Numerical Models: WRF}

The regional meteorological model used in this study is the WRF model with Advanced Research WRF (ARW) dynamic core [24], version 3.6, which has been developed for research and forecasting purposes for a large variety of specific objectives. WRF is a widely used NWP model with thousands of users worldwide that includes numerous options representing different physical processes. One useful capability of this model is its flexibility in choosing different dynamical and physical schemes. It may be employed at different atmospheric scales. In the model configuration used here, the following schemes were selected: Thompson et al. [25] microphysics, for the mixing ratios of cloud water, rain, cloud ice, snow, and graupel, plus the number concentrations of ice with prognostic variables; the Kain [26] cumulus parameterization in the coarser grid (no parameterization is used in the inner grid); the Rapid Radiative Transfer Model (RRTM) for longwave radiation, based on Mlawer et al. [27]; the Dudhia [28] scheme for shortwave radiation; the Monin-Obhukov-Janjic TKE scheme [29] for the planetary boundary layer; the Noah land-surface model [30].

In this study WRF model was used with two grids (Figure 1) with $12 \mathrm{~km}(70 \times 70)$ and $3 \mathrm{~km}(161 \times 141)$ horizontal spacing. Both domains have the same vertical structure, consisting of 39 levels that extend from 1000 to $25 \mathrm{hPa}$. The internal domain (d01) covers the extremity of the AP, target area of study, while the coarser grid (d01) covers the AP basin. Initial and boundary conditions have been provided by $1.0^{\circ} \times 1.0^{\circ}$ NCEP Global Final (FNL) analyses (http://rda.ucar.edu/datasets/ds083.2/), available every $6 \mathrm{~h}$. 


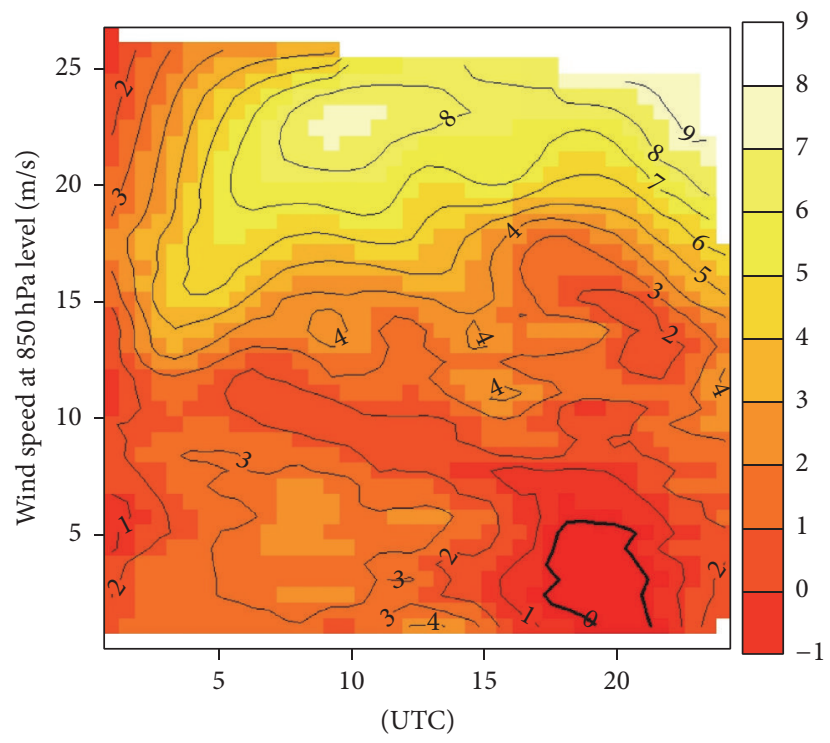

FIgURe 2: Mean divergence at the surface over the Antarctic Peninsula as a function of time of the day and the 850-hPa mean wind speed.

TABLE 1: Days with the occurrence of cloudiness due to the sea breeze convergence over AP for the years 2013, 2014, and 2015.

\begin{tabular}{cc}
\hline Year & Select days \\
\hline 2013 & $(12,14,15,19,24$ December; 2, 3 January $)$ \\
2014 & $(8,9,16,17,29,30,31$ December $)$ \\
2015 & (17 December; 9, 10, 11 January; 16, 17 February; 6 March) \\
\hline
\end{tabular}

\section{Period of the Analysis}

3.1. Selection of Days. Events are primarily selected from a subjective analysis of satellite images to exclude days with synoptic systems and/or extensive precipitation during the summer period of 2013-2015. This criterion left 59 days, which are simulated with WRF model. Among these days, 21 days presented a convergence zone in the AP, associated with the sea breeze. Figure 2 shows the mean divergence at the surface in the AP for the 59 simulated days, as a function of time of the day and wind at $850 \mathrm{hPa}$. Average negative divergence (thick black line) dominates only from 1700 to 2100 UTC, when the $850-\mathrm{hPa}$ wind speed is weaker than $6 \mathrm{~m} / \mathrm{s}$. Such a convergence is caused by the sea breeze, and the 21 days when it is reproduced by the model is considered in the present analysis. Table 1 shows the number of days with the occurrence of cloudiness, with sea breeze convergence on the peninsula.

At Esperanza station, located in the AP $(63.4 \mathrm{~S}$ and $57.0 \mathrm{~W})$, the summer temperature has risen by $2.1^{\circ} \mathrm{C}$ over the period of 1965-2004. This is a much larger warming than the global average [31] and such heating can favor the development of the sea breeze in the AP.

3.2. Synoptic Analysis. The synoptic conditions of the 21 selected days are identified based on composite means. These are calculated for the entire period from NCEP
(National Centre for Environmental Prediction) and NCAR (National Center for Atmospheric Research) reanalysis data (http://www.esrl.noaa.gov/psd/data/composites/day/).

The typical synoptic conditions of the sea breeze events are characterized by a high surface pressure at the western sector and central Antarctic, surrounded by low surface pressure systems around continent, except for the peninsula area (Figure 3(a)). The pressure gradient is relatively weak along the peninsula, being responsible for the weak synoptic wind with mean intensity of about $2 \mathrm{~m} / \mathrm{s}$ (Figure 3(f)). This characteristic favors the advection of moist air at low levels from the sea throughout the peninsula. Another important feature is the presence of a trough at $500 \mathrm{hPa}$ (Figure 3(b)), east of the peninsula. The cold air trough is present in $850 \mathrm{hPa}$ (Figure 3(c)) and at $500 \mathrm{hPa}$ (Figure 3(d)). In the same area, the $850-\mathrm{hPa}$ relative humidity reaches $80 \%$ (Figure $3(\mathrm{e})$ ).

Composite anomalies are calculated from the difference between the average of the selected days and the climatology. A large negative anomaly of $500-\mathrm{hPa}$ geopotential height (-60 gpm) happens north of the AP (Figure 4(a)). The sealevel pressure presents very strong anomalies that range from $-9 \mathrm{hPa}$ to $4 \mathrm{hPa}$ over the Antarctic as a whole, but no significant anomaly is found over the peninsula (Figure 4(b)), showing that breeze occurrence is favored under the absence of significant synoptic forcing. In contrast, temperature anomaly ranges from -1 to $-2 \mathrm{~K}$ over the peninsula, both at $850 \mathrm{hPa}$ (Figure 4(c)) and at $500 \mathrm{hPa}$ (Figure 4(d)). This result indicates that such cold anomalies are a feature which favor the breeze development (the breeze circulation is inhibited by high-pressure patterns).

\section{Sea Breeze Characteristics}

Figure 5 presents the sea breeze convergence over AP for three different synoptic conditions. In the first case (Figure 5(a)), when synoptic winds out of south-southwest prevail over 


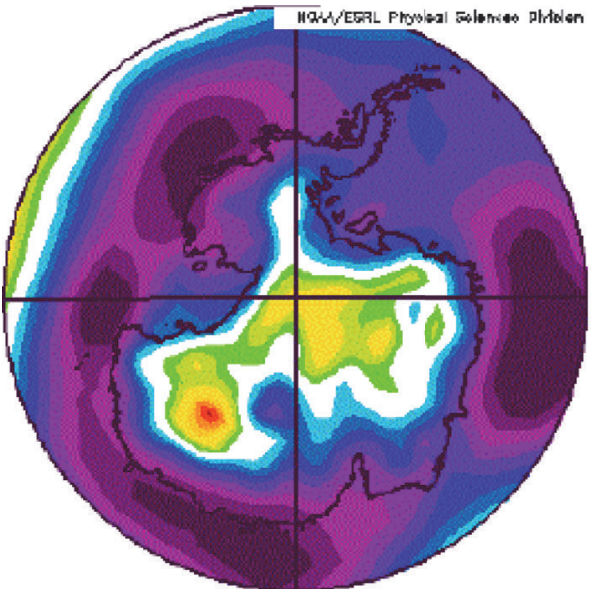

(a)

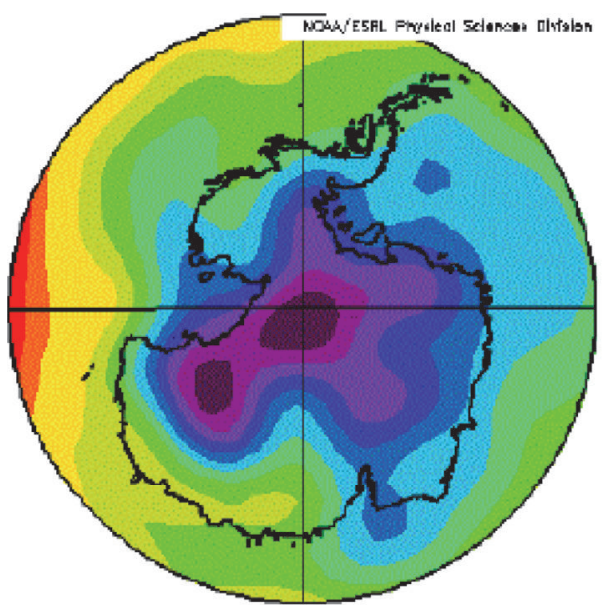

(c)

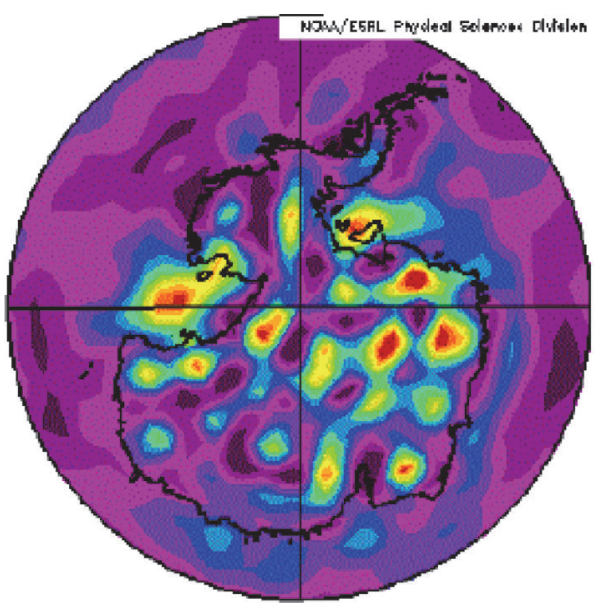

(e)
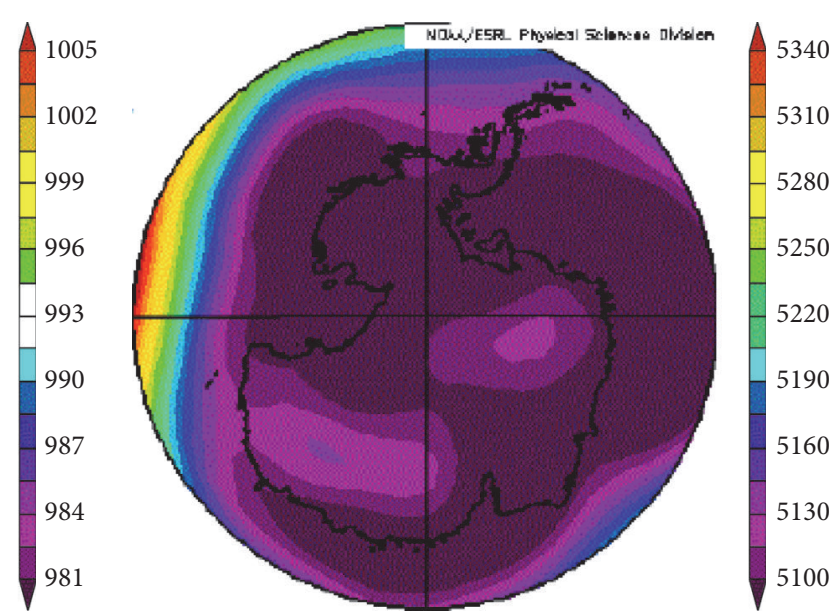

(b)
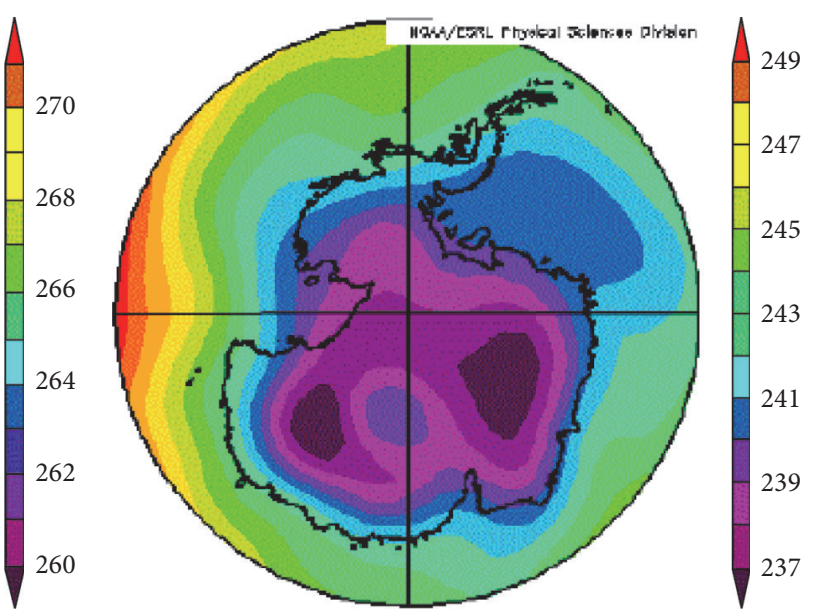

(d)
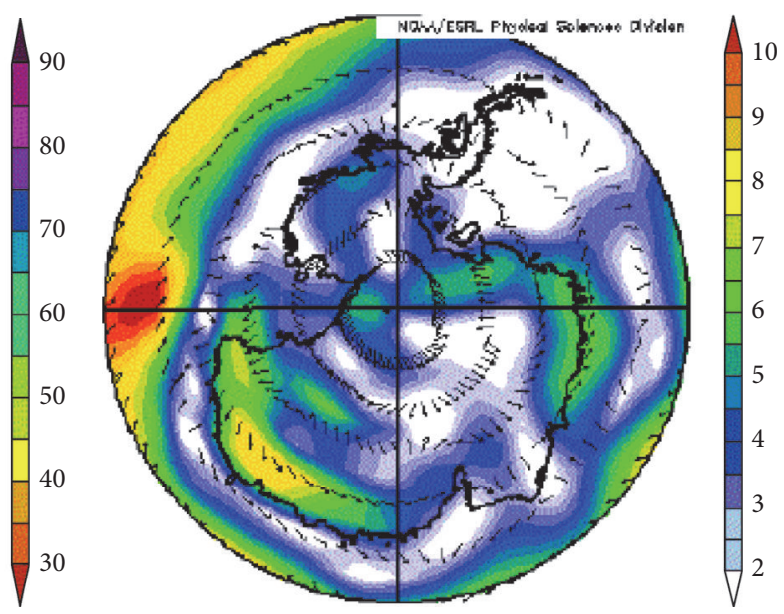

(f)

Figure 3: Mean fields over the detected 21 days: (a) mean sea-level pressure (hPa); (b) $500 \mathrm{hPa}$ geopotential height (gpm); (c) $850 \mathrm{hPa}$ air temperature (K); (d) $500 \mathrm{hPa}$ air temperature (k); (e) $850 \mathrm{hPa}$ relative humidity (\%); and (f) $1000 \mathrm{hPa}$ wind vector and speed (m/s) (source: http://www.esrl.noaa.gov/psd/data/composites/day/). 


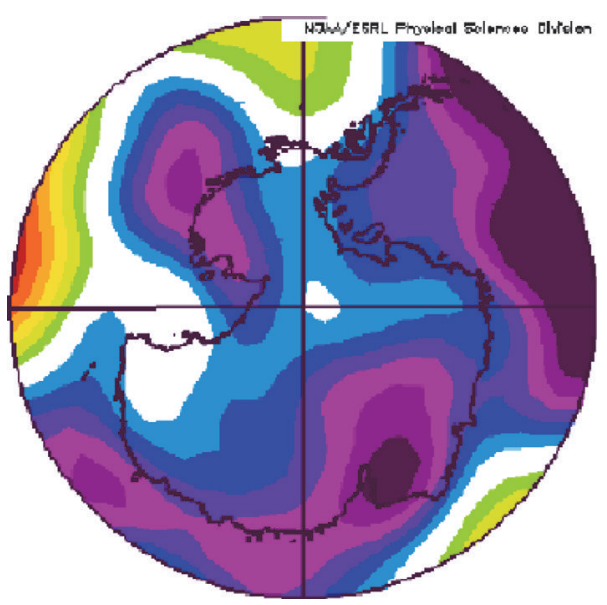

(a)

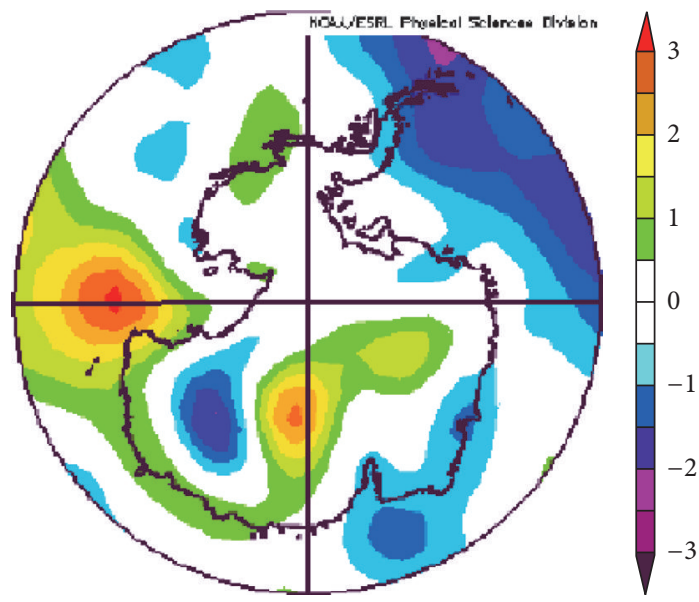

(c)
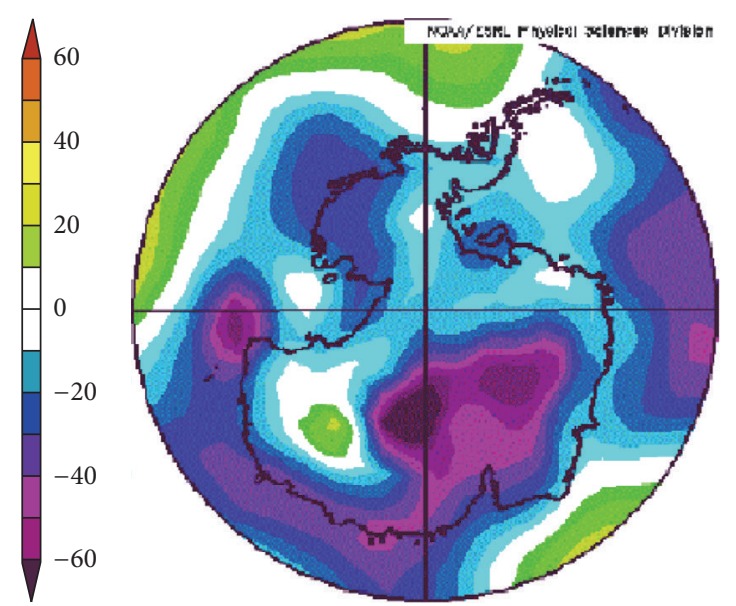

(b)

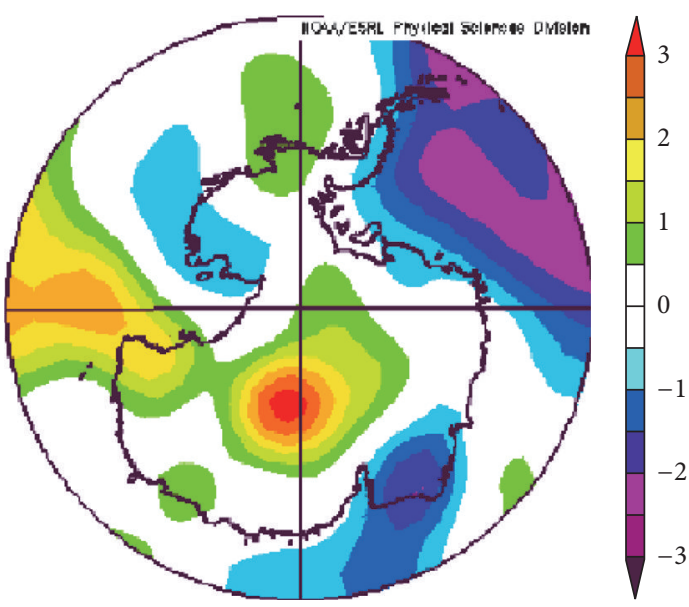

(d)

FIGURE 4: Mean anomaly fields over the detected 21 days with respect to the 40 -year climatology: (a) 500 hPa geopotential height (gpm); (b) sea-level pressure (hPa); (c) $850 \mathrm{hPa}$ air temperature (k); (d) $500 \mathrm{hPa}$ air temperature (K) (source: http://www.esrl.noaa.gov/psd/data/composites/day/).

the Weddell Sea, the sea breeze convergence front moves north, towards the Bransfield Strait coast. In the second case (Figure 5(b)), northerly winds prevail at the Bransfield Strait, and the breeze convergence front moves to the southern end of the AP, towards the coast of the Weddell Sea.

Finally, in the third case (Figure 5(c)) in the absence of any significant synoptic scale wind, the sea breeze convergence happens at the center of the AP.

Figures 6-8 shows three particular cases of wind convergence over the $\mathrm{AP}$, each caused by different offshore synoptic winds north and south of the peninsula. In the first case (Figure 6(a)), southwesterly winds happen south of the peninsula, at the Weddell Sea. The breeze convergence region in such a situation is shifted northward, approaching the northern AP coast. In the satellite image (Figure 6(b)), low clouds are apparent over the peninsula. When synoptic winds are weak both north and south of the AP, the sea breeze convergence is located towards the center of the peninsula (see Figures 7(a) and 8(a)). This has been also observed by Comin et al. [21] over the Salento Peninsula (Italy), for wind speeds lower than $4 \mathrm{~m} / \mathrm{s}$. They also found that, for higher wind speeds, the sea breeze convergence line is shifted away from the center of Salento Peninsula similarly as found in the present study over the AP. The presence of the two different sea breeze circulations (north and south), which converge near the center of the peninsula, is evident in the WRF simulations (Figures 7(a) and 8(a)), as well as a band of cloudiness along the peninsula at the satellite images (Figures 7(b) and 8(b)). The developing sea breeze in calm weather gradually extends further out to sea as well as inland [32].

For each event, the convergence may occur in more than one of the subregions at the same time (Bransfield Strait coast, center of the Antarctic Peninsula, and Weddell Sea coast). This is why there are 26 convergence events in the subregions for 21 days selected. In the area denoted as center of the AP, convergence occurred 15 times during the analyzed period, while it happened 8 times in Bransfield Strait coast and 4 times in the Weddell Sea coast.

At the northern portion of the AP, the large-scale flow generally operates in phase with the diurnal breeze at the 


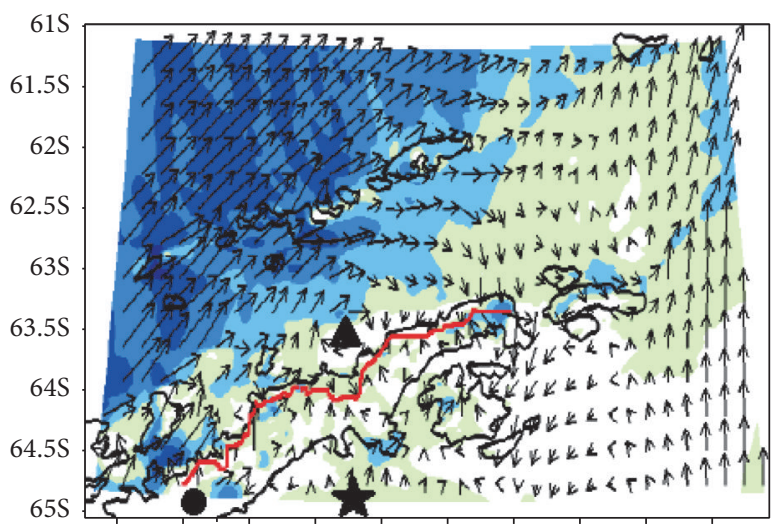

63W 62W 61W 60W 59W 58W 57W 56W 55W 54W

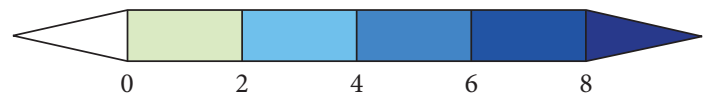

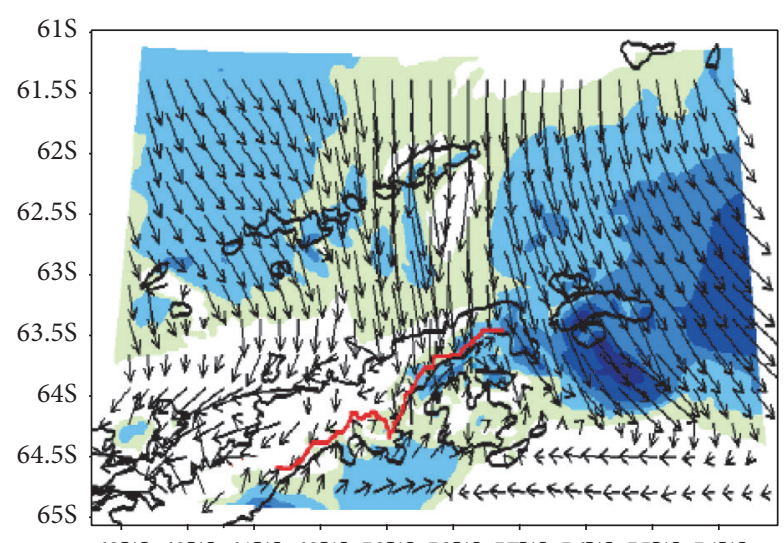

63W 62W 61W 60W 59W 58W 57W 56W 55W 54W

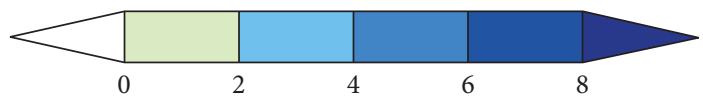

Bransfield Strait
Weddell Sea
Antarctic Peninsula

(b)

(a)

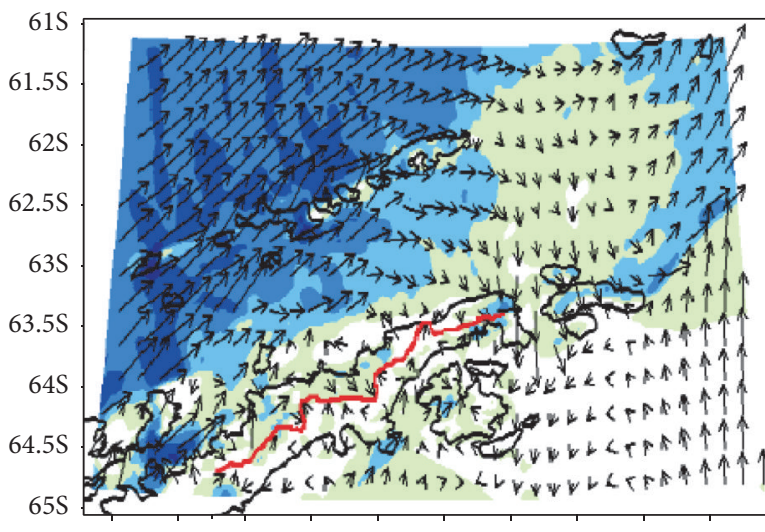

$63 \mathrm{~W} 62 \mathrm{~W} 61 \mathrm{~W} 60 \mathrm{~W} 59 \mathrm{~W} 58 \mathrm{~W} 57 \mathrm{~W} 56 \mathrm{~W} 55 \mathrm{~W} 54 \mathrm{~W}$
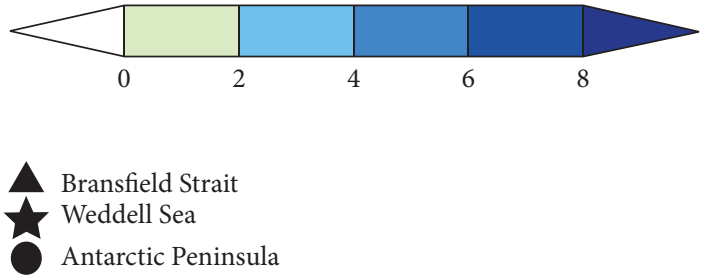

(c)

FIGURE 5: $10 \mathrm{~m}$ wind vectors and wind speed (m/s, color legend) for the following: (a) 29 December 2014 at 16:00 UTC; (b) 24 December 2013 at 12:00 UTC; (c) 29 December 2014 at 18:00 UTC, simulated with WRF. The red line marks the sea breeze convergence.

summer months, because winds from the west-northwest quadrant are much more frequent than those from east. The same pattern opposes the nocturnal breeze, while the opposite happens at the southern portion of the AP. Figure 9 shows the mean daily cycle of convergence over the entire AP, evidencing that the afternoon [21] and evening periods are those when convergence is most likely to occur, as has been shown in Figure 2. Given that the convergence increases the moisture at the low levels, this can be an important factor for the convective development.

The vertical profiles of the simulated potential temperature are studied to identify the vertical structure of the sea breeze circulation. The potential temperature gradient is another indicator of the development of the sea breeze. The 


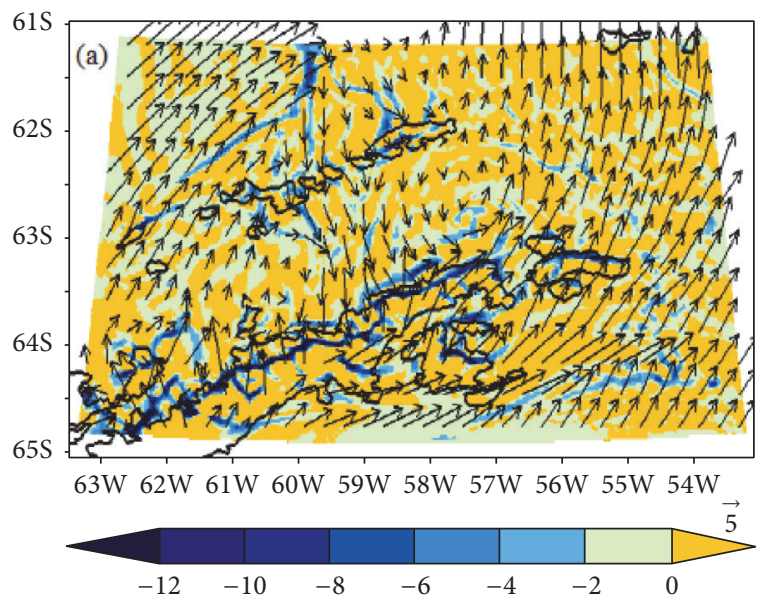

(a)

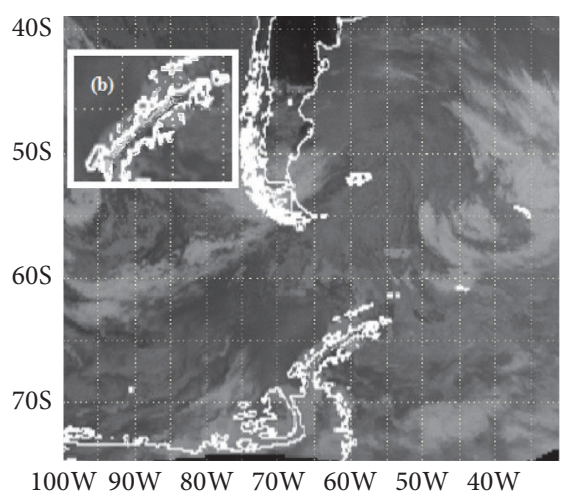

(b)

FIGURE 6: 15 December 2013: (a) $10 \mathrm{~m}$ wind vectors and horizontal divergence over the inner domain simulated with the WRF model at 22:00 UTC; (b) GOES 13 infrared image $(3.9 \mu$ channel) at 20:45 UTC. Inset shows a zoom over the peninsula (source: http://satelite.cptec.inpe.br/acervo/goes.formulario.logic).

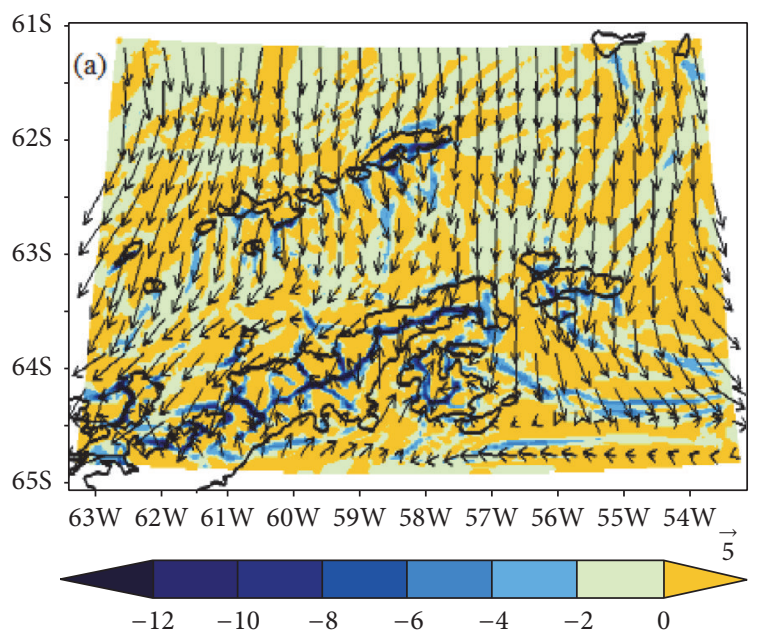

(a)

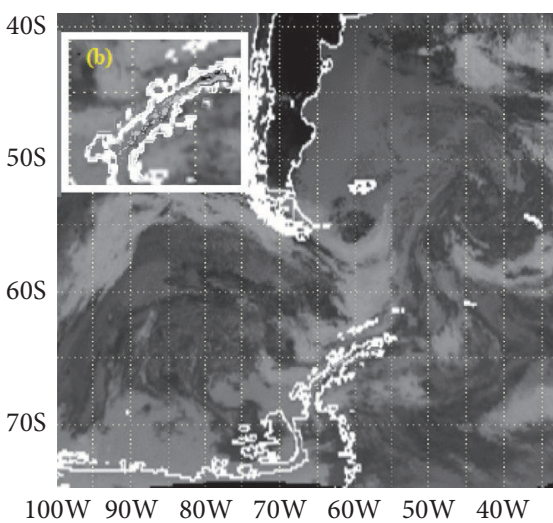

(b)

FIgURE 7: The same as in Figure 6, but for 24 December 2013, model output at 19:00 UTC and satellite image at 17:45 UTC.

largest gradients happen when the sea breeze occurs near the coastline, especially for a mature sea breeze [32]. The present results show large horizontal temperature gradients between the peninsula and the sea (Figure 10). The development of the sea breeze circulation system extends up to $1.2 \mathrm{~km}$ or higher. The vertical profiles of the simulated wind and potential temperature patterns are strongly affected by the topography, which marks a region of convergence or divergence, during the day and night, respectively. Topographically induced circulations may occur, enhancing the sea breeze circulation patterns. This figure shows the vertical wind pattern caused by the two different sea breeze circulation cells. High resolution WRF simulations show circulation cells that converge over the area of the peninsula. As the land warming continues in the afternoon, the sea breeze gradually intensifies and penetrates further inland. Topography plays an important role in the sea breeze circulation by aligning the sea breeze front to the coastline and by locating the convergence zones near the mountain [33]. Alcântara and de Souza [34] showed that the slope of a mountain intensifies the daytime sea breeze and similarly weakens the nighttime breeze. Thus, it is concluded that the complex topography that characterizes this area of study affects the development of sea breeze circulations.

Figure 11 shows the spatial variability of the sensible heat flux simulated during the mature sea breeze period. It reaches values ranging from 70 to $80 \mathrm{~W} / \mathrm{m}^{2}$ at the top of the mountains, while, at the lower altitude areas near the coast, the fluxes vary from 10 to $20 \mathrm{~W} / \mathrm{m}^{2}$. This sensible heat spatial distribution further enhances the sea breezes formation as the large sensible heat flux over the mountain deepens the local boundary layer and consequently the area 


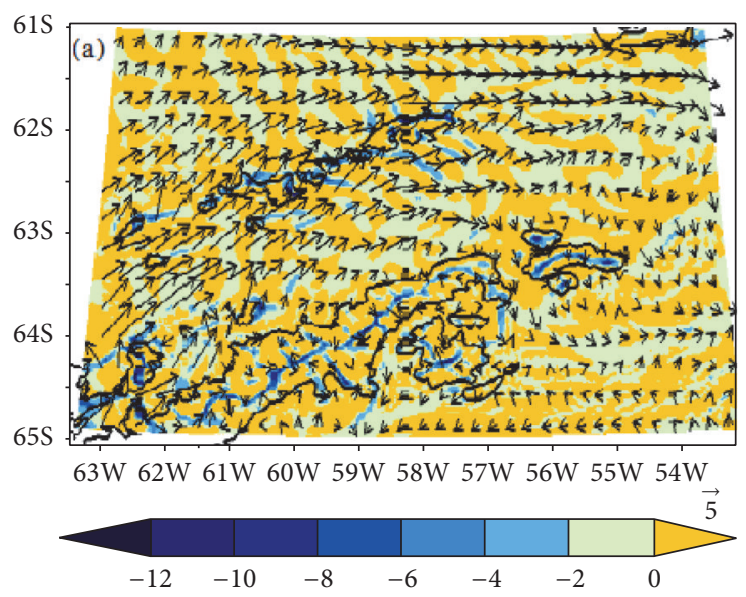

(a)

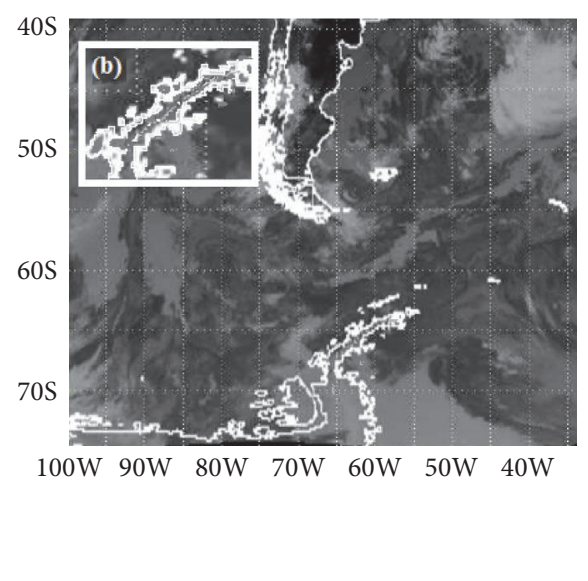

(b)

FIGURE 8: The same as in Figure 6, but for 31 December 2014, model output at 18:00 UTC and satellite image at 17:45 UTC.

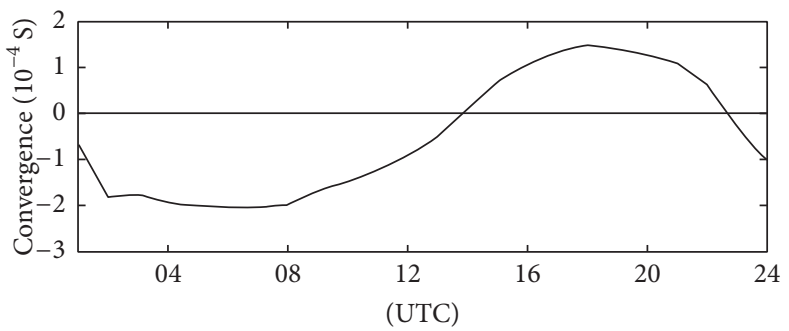

FIGURE 9: Daily cycle of sea breeze convergence over the surface for the 21 days.

with upward motion at the mountain tops. Miao et al. [33] showed that topography plays an important role in the sea breeze circulation by aligning the sea breeze front to the coastline and locating the convergence zones close to the mountain. If the mountain is elongated in the direction perpendicular to the flow, the diverted winds become lowlevel jets parallel to the ridge line [2].

\section{Conclusions}

The meteorological patterns associated with sea breeze systems over Antarctic Peninsula have been determined from synoptic maps. Satellite images have been used to discard days with cyclonic activity and extensive rainfall acting on the peninsula, leaving 59 days during the summers of 2013, 2014, and 2015. These days have been simulated with WRF model. In 21 of these 59 days, sea breeze convergence has been simulated. Such a convergence is weak and localized. The mean synoptic conditions that favor sea breeze convergence are a weak pressure gradient and also a weak synoptic wind $(\sim 2 \mathrm{~m} / \mathrm{s})$ north and south of the peninsula. This is a factor that favors the advection of moist air from the sea at low levels increasing the relative humidity to $80 \%$ in the area. The presence of a cold air trough east of the AP causes a strong negative geopotential anomaly of $-60 \mathrm{gpm}$ in the peninsula, while no significant pressure anomaly is present along the peninsula. The temperature anomaly ranges from -1 to $-2 \mathrm{~K}$ at $850 \mathrm{hPa}$ and $500 \mathrm{hPa}$, respectively. This cold anomaly favors the necessary horizontal thermal gradients to trigger the sea breeze circulations.

In simulations with the WRF model, there is a surface convergence band caused by the sea breeze, located in different areas of the peninsula. Most cases of convergence occur for synoptic wind less than $6 \mathrm{~m} / \mathrm{s}$ at $850 \mathrm{hPa}$. The vertical height of the sea breeze layer is usually less than $1.2 \mathrm{~km}$. In the transition zone between the sea and the peninsula, there is a strong potential temperature gradient in the afternoon, which favors the development of the sea breeze circulations. The combination between complex topography and mesoscale circulation affects the evolution of the sea breeze circulations.

The existence of two different sea breeze circulation cells, one to the south and another to the north, over the peninsula, is evident in the high resolution simulations using the WRF model. This phenomenon is evident during the sea breeze mature stage. These circulation cells that develop in the afternoon favor the advection of offshore low-level moist air. The localization of the convergence zone is determined by the synoptic wind speed, in a way that, for weak synoptic winds, the winds converge near the center of the peninsula. When the synoptic wind intensity is moderate, the convergence region moves towards the coast. The results of the present study show that WRF simulations, with a grid spacing of $3 \mathrm{~km}$, can be an adequate tool for the simulations of 


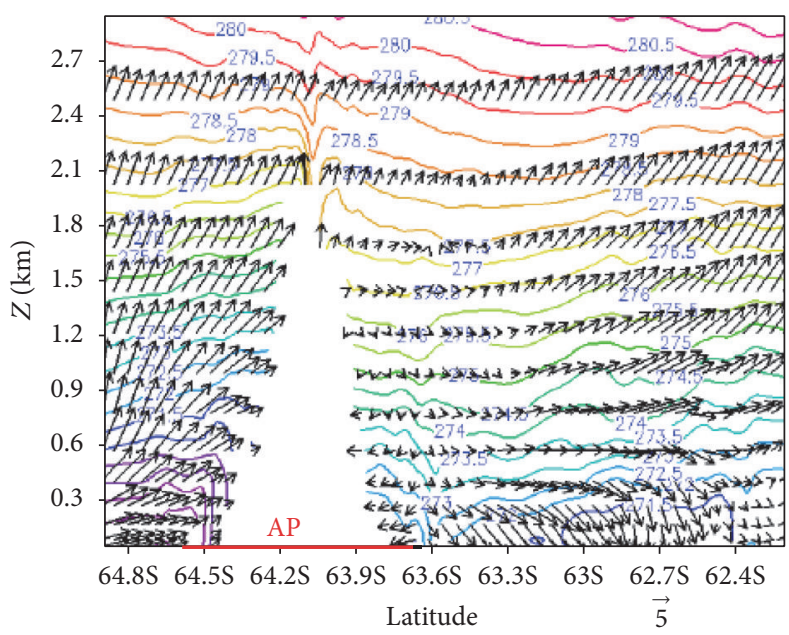

(a)

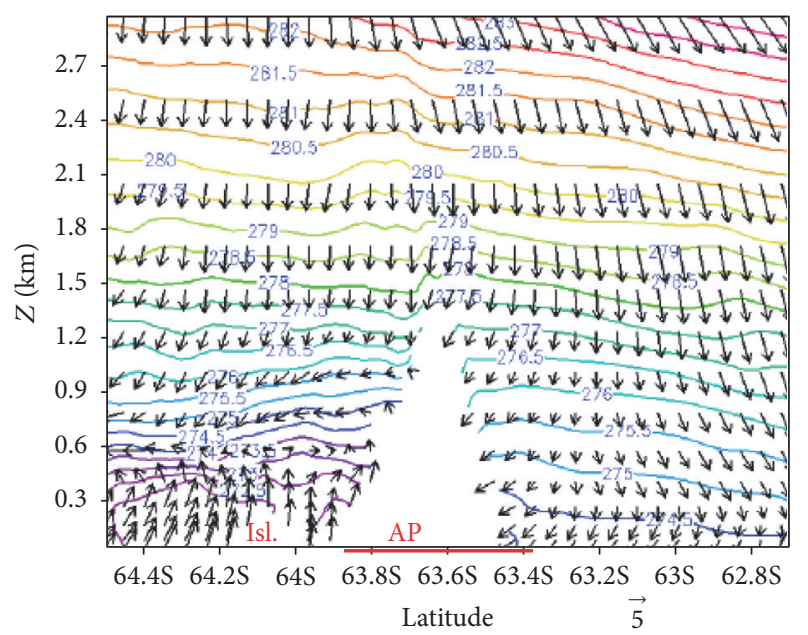

(c)

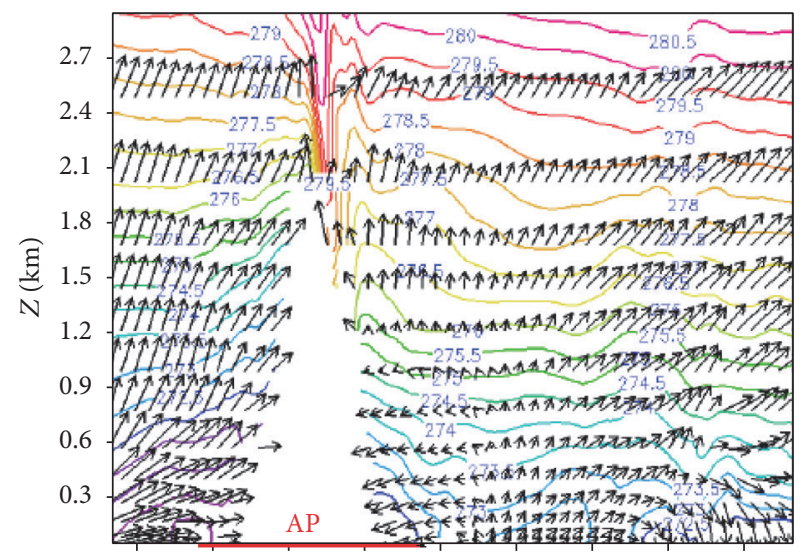

$\begin{array}{lllllllllll}64.8 S & 64.5 \mathrm{~S} & 64.2 \mathrm{~S} & 63.9 \mathrm{~S} & 63.6 \mathrm{~S} & 63.3 \mathrm{~S} & 63 \mathrm{~S} & 62.7 \mathrm{~S} & 62.4 \mathrm{~S}\end{array}$ Latitude

(b)

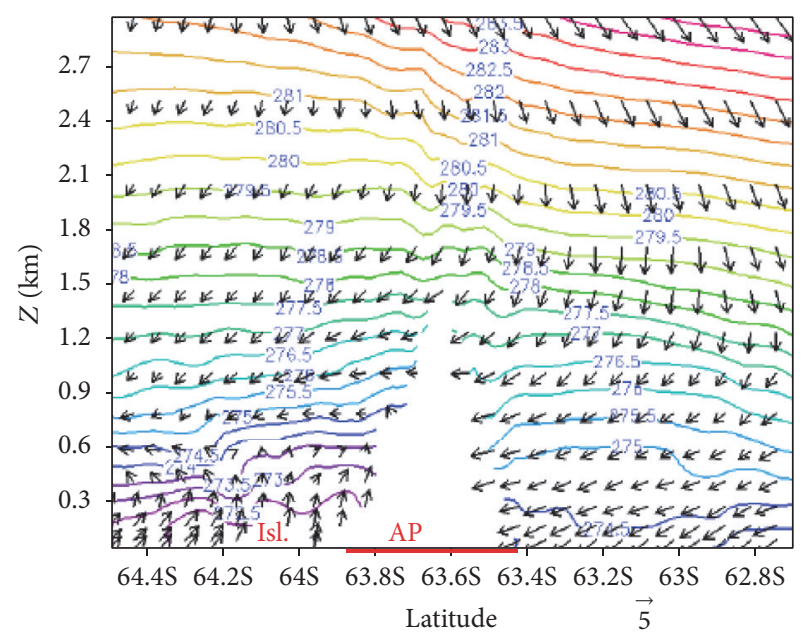

(d)

FIGURE 10: Vertical variation of wind vector and potential temperature for different longitudes. Latitude and height are shown in $x$ - and $y$ axes. $(\mathrm{a}, \mathrm{b})$ represent a cross section at longitude $59.1 \mathrm{~W}$, while $(\mathrm{c}, \mathrm{d})$ are at $58.45 \mathrm{~W}$. Time of the panels is as follows: (a) 15 December 2013 at 19:00 UTC; (b) 15 December 2013 at 22:00 UTC; (c) 24 December 2013 at 20:00 UTC; and (d) 24 December 2013 at 23:00 UTC. The white area in the bottom corresponds to the topography at the respective longitude, while the width of the peninsula (AP) is marked with a red thick line.

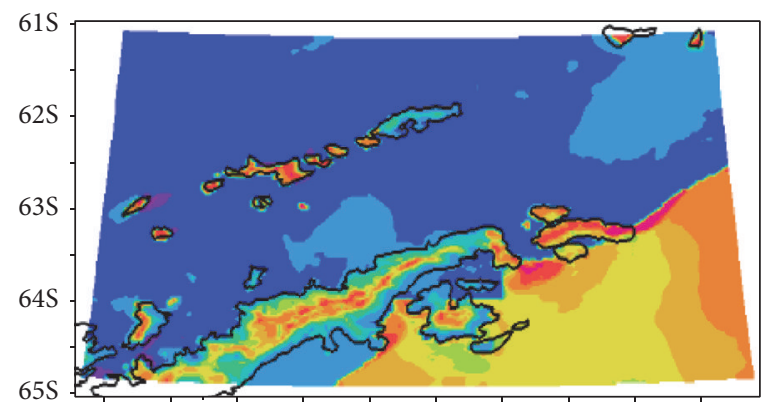

63W 62W 61W 60W 59W 58W 57W 56W 55W 54W

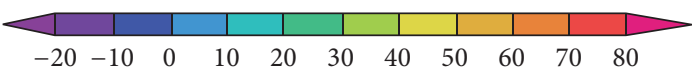

(a)

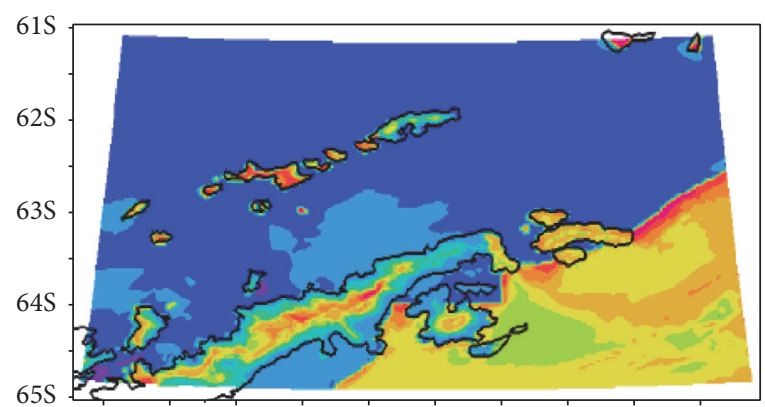

$63 \mathrm{~W} 62 \mathrm{~W} 61 \mathrm{~W} 60 \mathrm{~W} 59 \mathrm{~W} 58 \mathrm{~W} 57 \mathrm{~W} 56 \mathrm{~W} 55 \mathrm{~W} 54 \mathrm{~W}$

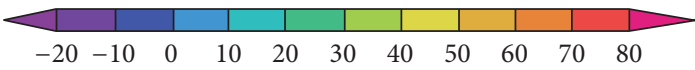

(b)

FIGURE 11: Sensible heat flux (W/m²) simulated with WRF: (a) 29 December 2014 at 19:00 UTC and (b) 30 December 2014 at 18:00 UTC. 
small-scale atmospheric phenomena such as the sea breeze convergence over Antarctic Peninsula.

\section{Competing Interests}

The authors declare that there is no conflict of interests regarding the publication of this paper.

\section{Acknowledgments}

The authors thank the Brazilian National Council for Scientific and Technological Development $(\mathrm{CNPq})$ and the INCT Criosfera (CNPq-704222/2009) for financial support of this work.

\section{References}

[1] D. L. Boyer and R.-R. Chen, "Laboratory simulation of mountain effects on large-scale atmospheric motion systems: the Rocky Mountains," Journal of the Atmospheric Sciences, vol. 44, no. 1, pp. 100-123, 1987.

[2] M. Georgelin and E. Richard, "Numerical simulation of flow diversion around the Pyrenees: a tramontana case study," Monthly Weather Review, vol. 124, no. 4, pp. 687-700, 1996.

[3] T. H. Nylen, A. G. Fountain, and P. T. Doran, "Climatology of katabatic winds in the McMurdo dry valleys, southern Victoria Land, Antarctica," Journal of Geophysical Research, vol. 109, no. 3, Article ID D03114, 2004.

[4] A. Orr, G. J. Marshall, J. C. R. Hunt et al., "Characteristics of summer airflow over the Antarctic Peninsula in response to recent strengthening of Westerly circumpolar winds," Journal of the Atmospheric Sciences, vol. 65, no. 4, pp. 1396-1413, 2008.

[5] G. J. Marshall, A. Orr, N. P. M. van Lipzig, and J. C. King, “The impact of a changing Southern Hemisphere annular mode on Antarctic Peninsula summer temperatures," Journal of Climate, vol. 19, no. 20, pp. 5388-5404, 2006.

[6] T. R. Parish, "The influence of the Antarctic Peninsula on the wind field over the western Weddell Sea," Journal of Geophysical Research, vol. 88, no. C4, p. 2684, 1983.

[7] J. M. van Wessem, C. H. Reijmer, W. J. van den et al., “Temperature and wind climate of the antarctic peninsula as simulated by a high-resolution regional atmospheric climate model," Journal of Climate, vol. 28, pp. 7306-7326, 2015.

[8] P. R. Holland, "The seasonality of Antarctic sea ice trends," Geophysical Research Letters, vol. 41, no. 12, pp. 4230-4237, 2014.

[9] T. H. Nylen, A. G. Fountain, and P. T. Doran, "Climatology of katabatic winds in the McMurdo dry valleys, southern Victoria Land, Antarctica," Journal of Geophysical Research D: Atmospheres, vol. 109, no. 3, pp. 1-9, 2004.

[10] C. Périard and P. Pettrè, "Some aspects of the climatology of dumont D’Irville, Adélie Land, Antarctica," International Journal of Climatology, vol. 13, pp. 313-328, 2003.

[11] P. Pettrè, C. Payan, and T. R. Parish, "Interaction of katabatic flow with local thermal effects in a coastal region of Adelie Land, east Antarctica," Journal of Geophysical Research, vol. 98, no. D6, pp. 10429-10440, 1993.

[12] G. Poljak, M. T. Prtenjak, M. Kvakić, N. Strelec Mahović, and K. Babić, "Wind patterns associated with the development of daytime thunderstorms over Istria," Annales Geophysicae, vol. 32, no. 4, pp. 401-420, 2014.
[13] J. E. Simpson, Sea Breeze and Local Wind, Cambridge University Press, 1994.

[14] J. González-Márquez and M. A. Heredia, "Sea-breeze convection in Mallorca," in Proceedings of the 5th National Symposium of Forecasting, pp. 1-6, Spanish Meteorological Agency, Madrid, Spain, 2001 (Spanish).

[15] J. M. Shephered, B. S. Ferrier, and P. S. Ray, "Rainfall morphology in Florida convergence zones: a numerical study," Monthly Weather Review, vol. 129, no. 2, pp. 177-197, 2001.

[16] S. I. Rani, R. Ramachandran, D. B. Subrahamanyam, D. P. Alappattu, and P. K. Kunhikrishnan, "Characterization of sea/land breeze circulation along the west coast of Indian sub-continent during pre-monsoon season," Atmospheric Research, vol. 95, no. 4, pp. 367-378, 2010.

[17] S. Federico, L. Pasqualoni, L. De Leo, and C. Bellecci, "A study of the breeze circulation during summer and fall 2008 in Calabria, Italy," Atmospheric Research, vol. 97, no. 1-2, pp. 1-13, 2010.

[18] C. Azorin-Molina, B. H. Connell, and R. Baena-Calatrava, "Sea-breeze convergence zones from AVHRR over the Iberian Mediterranean area and the Isle of Mallorca, Spain," American Meteorological Society, vol. 48, no. 10, pp. 2069-2085, 2009.

[19] J. L. Roberts, A. D. Moy, T. D. Van Ommen et al., "Borehole temperatures reveal a changed energy budget at Mill Island, East Antarctica, over recent decades," Cryosphere, vol. 7, no. 1, pp. 263-273, 2013.

[20] C. Ramis and S. Alonso, "Sea-breeze convergence line in Majorca: a satellite observation," Weather, vol. 43, no. 8, pp. 288293, 1988.

[21] A. N. Comin, M. M. Miglietta, U. Rizza, O. C. Acevedo, and G. A. Degrazia, "Investigation of sea-breeze convergence in Salento Peninsula (southeastern Italy)," Atmospheric Research, vol. 160, pp. 68-79, 2015.

[22] J. Mazon and D. Pino, "Role of the nocturnal coastal-front depth on cloud formation and precipitation in the Mediterranean basin," Atmospheric Research, vol. 153, pp. 145-154, 2015.

[23] M. A. Jiménez, G. Simó, B. Wrenger, M. Telisman-Prtenjak, J. A. Guijarro, and J. Cuxart, "Morning transition case between the land and the sea breeze regimes," Atmospheric Research, vol. 172-173, pp. 95-108, 2016.

[24] W. C. Skamarock, J. B. Klemp, J. Dudhia et al., "A description of the advanced research WRF Version 3," NCAR Technical Note NCAR/TN 475, 2008.

[25] G. Thompson, R. M. Rasmussen, and K. Manning, "Explicit forecasts of winter precipitation using an improved bulk microphysics scheme. Part I: description and sensitivity analysis," Monthly Weather Review, vol. 132, no. 2, pp. 519-542, 2004.

[26] J. S. Kain, "The Kain-Fritsch convective parameterization: an update," Journal of Applied Meteorology, vol. 43, no. 1, pp. 170181, 2004.

[27] E. J. Mlawer, S. J. Taubman, P. D. Brown, M. J. Iacono, and S. A. Clough, "Radiative transfer for inhomogeneous atmospheres: RRTM, a validated correlated-k model for the longwave," Journal of Geophysical Research D, vol. 102, no. 14, pp. 16663-16682, 1997.

[28] J. Dudhia, "Numerical study of convection observed during the Winter Monsoon Experiment using a mesoscale two-dimensional model," Journal of the Atmospheric Sciences, vol. 46, no. 20, pp. 3077-3107, 1989.

[29] Z. I. Janjic, "Nonsingular implementation of the Mellor-Yamada level 2.5 scheme in the NCEP Meso model," NCEP, Technical Representative, vol. 437, p. 61, 2001. 
[30] G.-Y. Niu, Z.-L. Yang, K. E. Mitchell et al., "The community Noah land surface model with multiparameterization options (Noah-MP): 1. Model description and evaluation with localscale measurements," Journal of Geophysical Research Atmospheres, vol. 116, no. 12, Article ID D12109, 2011.

[31] N. P. M. van Lipzig, G. J. Marshall, A. Orr, and J. C. King, "The relationship between the Southern Hemisphere annular mode and antarctic Peninsula summer temperatures: analysis of a high-resolution model climatology," Journal of Climate, vol. 21, pp. 1649-1668, 2008.

[32] R. W. Arritt, "Effects of the large-scale flow on characteristic features of the sea breeze," Journal of Applied Meteorology, vol. 32, no. 1, pp. 116-125, 1993.

[33] J.-F. Miao, L. J. M. Kroon, J. V.-G. de Arellano, and A. A. M. Holtslag, "Impacts of topography and land degradation on the sea breeze over eastern Spain," Meteorology and Atmospheric Physics, vol. 84, no. 3-4, pp. 157-170, 2003.

[34] C. R. Alcântara and E. P. de Souza, "A thermodynamic theory for breezes: test using numeric simulations," Brazilian Journal of Meteorology, vol. 23, no. 1, pp. 1-11, 2008. 

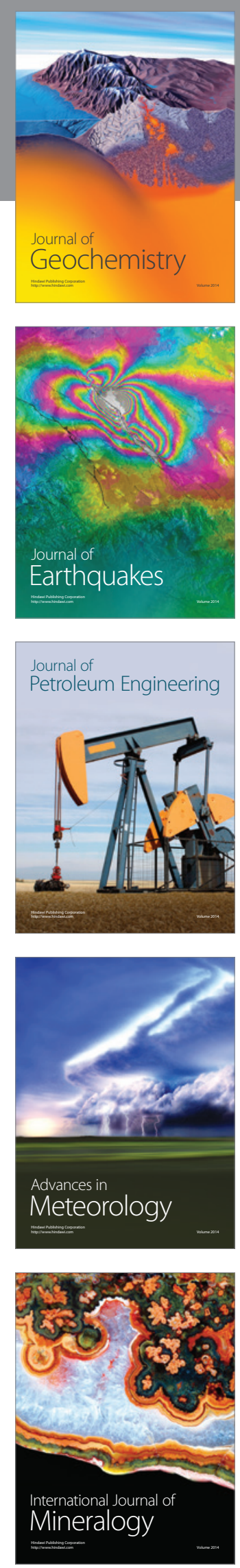
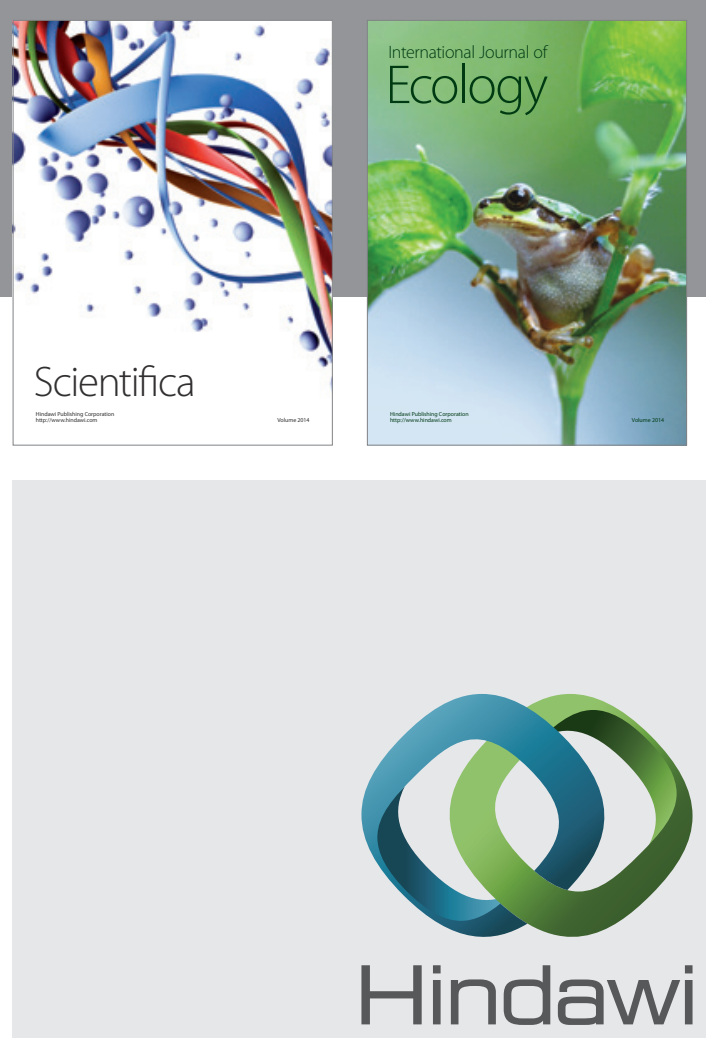

Submit your manuscripts at

https://www.hindawi.com
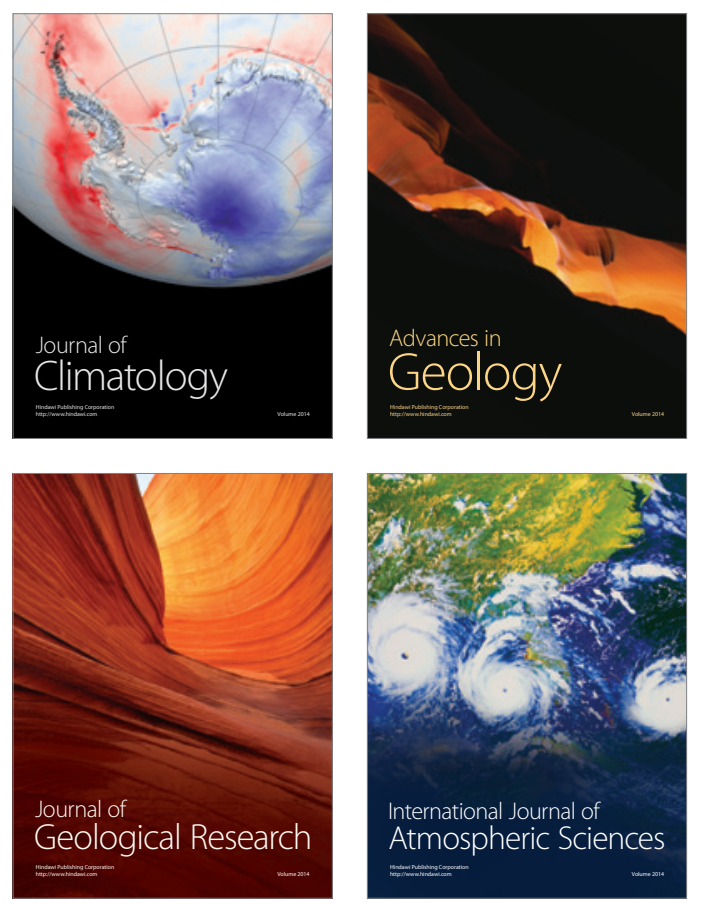

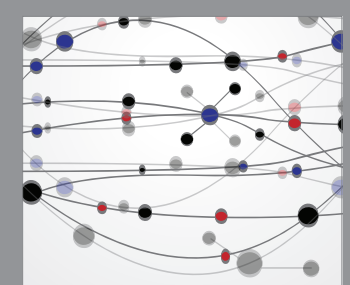

The Scientific

\section{World Journal}
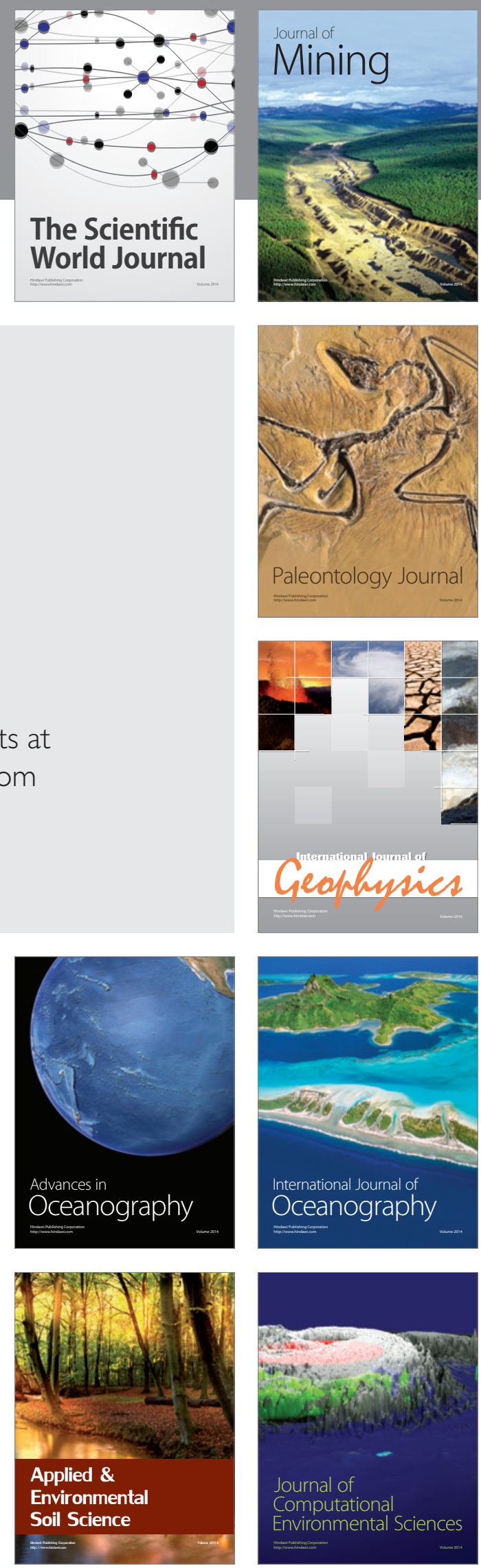